\title{
Timing and duration of hatching in gynogenetic, triploid, tetraploid, and hybrid progenies in rainbow trout
}

\author{
Edwige QUILLET, B. CHEVASSUS and A. DEVAUX ${ }^{(1)}$ \\ Institut National de la Recherche Agronomique, Laboratoire de Génétique des Poissons, \\ 78350 Jouy-en-Josas, France
}

\begin{abstract}
Summary
Mean duration of embryonic development and variability of this parameter were studied for seven different progenies in rainbow trout : diploid controls, diploid gynogenetics, triploids resulting from heat shock or from a direct cross between diploid female and tetraploid male, tetraploids, and diploid or triploid hybrids between female rainbow trout and male coho salmon. The main results were : (1) gynogenesis does not change mean duration of embryonic development, but induces larger variability of this parameter ; $(2)$ the higher the ploidy level the shorter the duration of embryonic development : tetraploids hatch before the two types of triploids, which hatch before the diploid controls. On the other hand, within group variability of hatching time is generally greater in these groups than in the control ; (3) in the case of interspecific hybridization, triploidy also reduces duration of embryonic development, relatively to diploid hybrids, but induces greater homogeneity in hatching times than in diploid hybrids.
\end{abstract}

Key words : salmonids, polyploidy, gynogenesis, hybridization, hatching.

\section{Résumé}

Date et durée d'éclosion de descendances gynogénétiques, triploïdes, tétraploïdes et hybrides chez la truite arc-en-ciel

La vitesse moyenne de développement embryonnaire (mesurée par la date d'éclosion) et sa variabilité ont été étudiées dans sept types de descendances chez la truite arc-en-ciel : des témoins diploïdes, des gynogénétiques diploïdes, des triplö̈des obtenus par rétention du second globule polaire (choc thermique chaud) et des triploides obtenus par croisement direct entre une femelle diploïde et un mâle tétraploïde, des tétraplö̈des et des hybrides diplö̈des ou triploïdes entre la femelle truite arc-en-ciel et le mâle saumon coho. Les principaux résultats sont les suivants : (1) la gynogenèse ne modifie pas la durée moyenne de développement embryonnaire, mais provoque une plus grande dispersion des dates d'éclosion ; (2) plus le niveau de plö̈die est élevé, plus la durée de développement embryonnaire est réduite : les tétraplö̈des éclosent avant les deux types de triploïdes, qui éclosent eux-mêmes avant le témoin diploïde. Ces groupes présentent par contre une dispersion des éclosions généralement supérieure à celle du témoin ; (3) chez les hybrides interspécifiques, la triplö̈die est également associée à une réduction de la durée de développement embryonnaire par rapport à l'hybride diploïde, et diminue la variabilité des dates d'éclosion par rapport à celle de l'hybride diploïde.

Mots clés : salmonidés, polyplödie, gynogenèse, hybridation, éclosion.

(1) Present address : Laboratoire de Pharmacie et Toxicologie, ENV, 69260 Marcy-L'Etoile, France. 


\section{Introduction}

Chromosome engineering techniques have become widely used in fish in recent years (Purdom, 1983 ; Purdom et al., 1985 ; ThorgaArd, 1983, 1986). In the case of salmonids, direct manipulation of caryogamy or of meiotic and mitotic events allows production of different groups, including viable diploid gynogenetics resulting from inhibition of second meiotic division (Chourrout, 1980 ; ReFstie et al., 1982 ; ONOZATO, 1984), autotriploids obtained by retention of second polar body (Chourrout \& Quillet, 1982 ; Chourrout, 1984 ; Lou \& Purdom, 1984 ; Benfey \& Sutterlin, 1984 ; JoHnStone, 1985), and allotriploids, that may be more viable than diploid hybrids from same parental species (Chevassus et al., 1983 ; Scheerer \& ThorgaArd, 1983).

More recently, autotetraploids were induced by inhibition of first cleavage (THoRGAARD et al., 1981 ; Chourrout, 1982, 1984). These tetraploids proved to be fertile, and to give diploid sperm (Chourrout et al., 1986) and eggs (Chourrout \& NaKayama, 1987), offering opportunities to induce new kinds of diploid gynogenetics, triploids or tetraploids (see previous authors). These different groups, all of wide potential interest for genetic improvement, differ from diploid populations in ploidy level or consanguinity, two factors likely to influence and modify developmental kinetics and growth rate. Indeed, several results indicate actual differences in growth between gynogenetic and polyploid rainbow trout (see review of CHEvassus, 1987) as well as rainbow trout-coho salmon hybrids (Chevassus et al., 1985 ; Quillet, 1986) and their diploid rainbow trout control. Study of very early developmental stages is expected to bring complementary information on this point. More particularly, hyperplasia having been shown to play a prevalent role in growth of rainbow trout (LuQuer \& DurAND, 1970), the hypothesis may be advanced that long term differences in growth at least partly originate in different mitotic activity rates. Therefore, analysis of embryonic developmental rate, which also depends among other factors on mitotic activity rate, could eventually provide predicting factors of long term performances. This paper describes the effects of gynogenesis, triploidy, tetraploidy and hybridization on kinetics of early developmental stages (up to hatching) in rainbow trout.

\section{Material and methods}

Two different experiments were carried out in January 1981 and December 1984.

\section{A. Experiment $n^{\circ} 1$}

\section{Collecting gametes}

Broodstock were kept in the experimental fish farm of Gournay-sur-Aronde (temperature : 6 to $15^{\circ} \mathrm{C}$ ). Eggs of four rainbow trout females (Salmo gairdneri, INRA strain, three years old) were collected by abdominal pressure, and kept in separate batches at about $4{ }^{\circ} \mathrm{C}$. Milt was provided by 5 to 6 rainbow trout and coho salmon (Oncorhynchus kisutch) males. 


\section{Irradiation of sperm}

Two aliquots of both rainbow trout and coho salmon sperm were irradiated $(130 \mathrm{krad})$ as described by Chourrout (1980). Non-irradiated samples were kept at $4{ }^{\circ} \mathrm{C}$.

\section{Fertilization procedure}

The different groups produced from individual females are presented in table 1. Simple fertilization with irradiated rainbow trout or coho salmon sperm produced two haploid gynogenetic groups (HR and HC respectively), that are a control of irradiation efficiency and frequency of spontaneous diploid ova. Diploid gynogenetics (GR and GC, with respect to sperm origin), and triploid rainbow trout (heat-shock triploids symbolized as hs-R3) were induced by application of thermal shock, according to Chourrout \& Quillet (1982) $\left(26^{\circ} \mathrm{C}\right.$ for $20 \mathrm{~min}, 25 \mathrm{~min}$ after fertilization). The same shock allowed induction of triploid hybrids $\mathrm{R} 2 \mathrm{C}$ as described by Chevassus et al. (1983).

TABLE 1

Experimental set in experiment 1

\begin{tabular}{c|c|c|c|c}
\hline \multirow{2}{*}{$\begin{array}{c}\text { So } \\
\text { (S. gairdneri) }\end{array}$} & \multicolumn{2}{|c|}{ Salmo gairdneri (R) } & \multicolumn{2}{|c}{ Oncorhynchus kisutch (C) } \\
\cline { 2 - 5 } $\begin{array}{c}\text { No treatment } \\
\text { of ova } \\
\text { sperm }\end{array}$ & $\begin{array}{c}\text { Haploid } \\
\text { gynogenetic } \\
\text { (HR) }\end{array}$ & $\begin{array}{c}\text { Normal } \\
\text { sperm }\end{array}$ & $\begin{array}{c}\text { Irradiated } \\
\text { sperm }\end{array}$ & $\begin{array}{c}\text { Normal } \\
\text { sperm }\end{array}$ \\
\hline $\begin{array}{c}\text { Eontrol } \\
\text { Early }\end{array}$ & $\begin{array}{c}\text { Haploid } \\
\text { gynogenetic } \\
\text { (HC) }\end{array}$ & $\begin{array}{c}\text { Diploid } \\
\text { hybrid } \\
\text { (RC) }\end{array}$ \\
\hline \hline
\end{tabular}

In all cases, sperm and eggs were mixed and added with saline buffered diluent (BILlard, 1977) for 10 minutes. The inseminated eggs were then rinsed and transferred to a normal freshwater recirculating system, thermoregulated at $10^{\circ} \mathrm{C} \pm 0.5^{\circ} \mathrm{C}$.

\section{B. Experiment $n^{\circ} 2$}

The groups studied in this experiment were sampled from the experiment described by Chourrout et al. (1986) in rainbow trout. Four groups were analysed (diploid controls, two types of triploids and tetraploids) and are presented in table 2. Direct cross triploids (dc-R3) were induced by direct crossing of diploid females and tetraploid males; the same cross plus heat shock provided second generation tetraploids (R4). Fertilization and heat shock procedures are detailed in CHOuRrout et al. (1986). 
TABle 2

Experimental set in experiment 2

\begin{tabular}{|c|c|c|}
\hline (S. gairdneri) & $\begin{array}{l}\text { Diploid } \\
\text { (3 males) }\end{array}$ & $\begin{array}{l}\text { Tetraploid } \\
\text { (5 males) }\end{array}$ \\
\hline $\begin{array}{l}\text { No treatment } \\
\text { of ova }\end{array}$ & $\begin{array}{c}\text { Diploid control } \\
\text { (R2) }\end{array}$ & $\begin{array}{l}\text { Triploid } \\
\text { (dc-R3) }\end{array}$ \\
\hline $\begin{array}{c}\text { Early } \\
\text { heat shock }\end{array}$ & $\begin{array}{l}\text { Triploid } \\
\text { (hs-R3) }\end{array}$ & $\begin{array}{l}\text { 2nd generation } \\
\text { tetraploid } \\
\text { (R4) }\end{array}$ \\
\hline
\end{tabular}

\section{Nature of progenies}

In experiment 1 , the nature of the embryos and fry was determined by karyological and biochemical controls at the eyed stage, or on swimming fry (see Chourrout \& Quillet, 1982 ; Chevassus et al., 1983). In experiment 2, karyological analyses confirmed the expected nature of the different progenies (in Chourrout et al., 1986).

TABLE 3

Mean survival rates at hatching

\begin{tabular}{c|c|c}
\hline & Experiment 1 & Experiment 2 \\
\hline Hroups & 0 & \\
\hline HR & 47.1 & 82.4 \\
\hline GC & 66.1 & 91.9 \\
\hline R2 & 86.6 & 62.8 \\
\hline hs-R3 & 87.4 & 61.0 \\
\hline dc-R3 & & \\
\hline R4 & & \\
\hline RC & 52.1 & \\
\hline R2C & 83.1 & \\
\hline
\end{tabular}

Survival is calculated as (number of hatched fry/initial number of ova) $\times 100$.

(See tables 1 and 2 for the definition of the group symbols). 


\section{Survival rates}

Survival rates from fertilization to hatching were recorded (table 3) but are not analysed in detail in this paper.

\section{E. Hatching parameters}

Hatching curves were established by counting hatched fry (dead or alive) twice a day in batches of 100 embryos per group.

As a matter of fact, early hatched fry were likely to cause nearby fish to hatch prematurely and therefore could contribute to reducing total duration of hatching. This effect was demonstrated by CHEvassus (unpublished data) but appeared quite limited, so that we did not remove hatched fry from batches.

Water temperature was recorded continuously and was about $9^{\circ} \pm 0.5^{\circ} \mathrm{C}$ in experiment 1 and $10^{\circ} \pm 1^{\circ} \mathrm{C}$ in experiment 2. Durations of development were expressed in degree ${ }^{\circ} \mathrm{C} \times$ day $\left({ }^{\circ} \mathrm{C} . \mathrm{d}\right)$ received from fertilization.

Hatching parameters were calculated from the probit regression lines which were established by the probit transformation (FINNEY, 1962) of the portions of the hatching curves comprised between 10 and $90 \%$ of hatched fry. Mean time of hatching $(T H)$ was defined as being the time in $\left({ }^{\circ} \mathrm{C}\right.$.d) when $50 \%$ of the fry hatched, and duration of hatching $(D H)$ as the time (in ${ }^{\circ} \mathrm{C} . \mathrm{d}$ ) comprised between 10 and $90 \%$ of hatched fry.

Duration of hatching $(D H)$ was estimated by the time in ${ }^{\circ} \mathrm{C} . \mathrm{d}$ between 10 and $90 \%$ of hatched fry, calculated from linear regression parameters.

In experiment 1 , a linear model with fixed treatment effects and unequal but proportional sub-class numbers (SNEDECOR, 1956) as well as the non-parametric Friedman's test (SoKAL \& RoHLF, 1981) were used to perform statistical analyses.

Paired comparisons were substantiated by Student's $t$ test. According to regression assumptions, regression slope values were analysed to perform statistical analysis of duration of hatching.

\section{Results}

\section{A. Embryonic development duration}

1. Experiment $n^{\circ} 1$ (tables 4 and 5, figure 1)

A large effect of genetic nature of progenies is observed on embryonic development duration (Friedman's $\left.\chi^{2}(5 \mathrm{df})=18.3, P<0.01\right)$ :

- gynogenetic progenies (GR and GC) hatch at the same time as diploid controls (371.0 and $370.5^{\circ} \mathrm{C} . \mathrm{d}$ versus 367.4 in the controls) ;

- the duration of embryonic development in diploid and triploid hybrids is in any case longer than for diploid rainbow trout controls $\left(+73.0\right.$ to $+94.8^{\circ} \mathrm{C} . \mathrm{d}$ depending on female in $\mathrm{RC}$ groups, +51.8 to $+63{ }^{\circ} \mathrm{C} . \mathrm{d}$ in $\mathrm{R} 2 \mathrm{C}$ groups) ;

- triploid groups hatch before their diploid sibs, both in pure rainbow trout $(\mathrm{TH}$ is reduced $13^{\circ} \mathrm{C} . \mathrm{d}$ relative to the $\mathrm{R} 2$ group) and in hybrid groups $\left(25^{\circ} \mathrm{C} . \mathrm{d}\right.$ mean reduction).

No female effect is observed for this parameter. 
TABLE 4

Time of hatching $\left(\mathrm{TH}\right.$ in $\left.{ }^{\circ} \mathrm{C} . d\right)$ and duration of hatching $\left(\mathrm{DH}\right.$ in $\left.{ }^{\circ} \mathrm{C} . d\right)$ in experiment 1

\begin{tabular}{c|c|r|r|r|r|r|r}
\hline \multicolumn{2}{c|}{ Group } & GR & GC & R2 & hs-R3 & RC & R2C \\
\hline \multirow{2}{*}{ Female } & $T H$ & $371.8 \pm 1.5$ & $373.4 \pm 3.7$ & $363.6 \pm 2.1$ & $352.4 \pm 2.1$ & $450.9 \pm 2.8$ & $421.2 \pm 2.1$ \\
& $D H$ & $48.2 \pm 0.1$ & $51.0 \pm 0.2$ & $28.0 \pm 0.2$ & $35.4 \pm 0.2$ & $53.2 \pm 0.1$ & $34.2 \pm 0.2$ \\
\hline \multirow{2}{*}{2} & $T H$ & $380.4 \pm 1.0$ & $373.1 \pm 1.3$ & $366.9 \pm 1.6$ & $363.5 \pm 1.3$ & $461.7 \pm 2.1$ & $427.9 \pm 3.6$ \\
& $D H$ & $32.0 \pm 0.2$ & $45.7 \pm 0.1$ & $27.5 \pm 0.2$ & $33.2 \pm 0.1$ & $52.6 \pm 0.1$ & $56.5 \pm 0.2$ \\
\hline \multirow{2}{*}{3} & $T H$ & $364.9 \pm 1.3$ & $365.2 \pm 1.0$ & $375.1 \pm 0.8$ & $346.4 \pm 8.8$ & $448.1 \pm 3.1$ & $426.9 \pm 1.2$ \\
& $D H$ & $24.5 \pm 0.2$ & $29.3 \pm 0.1$ & $28.1 \pm 0.1$ & $55.6 \pm 0.2$ & $51.2 \pm 0.1$ & $21.7 \pm 0.2$ \\
\hline \multirow{2}{*}{4} & $T H$ & $366.8 \pm 3.8$ & $370.2 \pm 1.1$ & $364.0 \pm 0.6$ & $355.4 \pm 1.8$ & $441.8 \pm 6.6$ & $427.0 \pm 2.7$ \\
& $D H$ & $41.7 \pm 0.2$ & $33.5 \pm 0.1$ & $14.5 \pm 0.2$ & $30.4 \pm 0.2$ & $74.9 \pm 0.1$ & $50.5 \pm 0.2$ \\
\hline \multirow{2}{*}{ Mean } & $T H$ & 371.0 & 370.5 & 367.4 & 354.4 & 450.6 & 425.8 \\
& $D H$ & 36.6 & 39.9 & 24.5 & 38.7 & 58.0 & 40.7 \\
\hline
\end{tabular}

Table gives experimental values and confidence intervals for $P=0.05$.

(See table 1 for the definition of the group symbols).

TABLE 5

Results of two-way analysis of variance (data from experiment 1)

\begin{tabular}{c|l|r|r|r|r}
\hline \hline & Source of variation & df & \multicolumn{1}{c|}{ SS } & MS & F \\
\hline $\begin{array}{c}\text { Duration of } \\
\text { embryonic development } \\
(T H)\end{array}$ & Between group & 5 & 177058.5 & 35411.7 & 12692.4 \\
& Between female & 3 & 1929.1 & 643.0 & 230.5 \\
& Interaction & 15 & 180817.9 & 12054.5 & $4320.6^{(* *)}$ \\
& Within group & 123 & & 2.8 & \\
\hline Duration of & Between group & 5 & $437.310^{-2}$ & $87.510^{-2}$ & 137.3 \\
hatching & Between female & 3 & $70.010^{-2}$ & $23.510^{-2}$ & 36.8 \\
$(D H)$ & Interaction & 15 & $426.110^{-2}$ & $28.510^{-2}$ & $44.9^{(* *)}$ \\
& Within group & 123 & & $0.610^{-2}$ & \\
\hline
\end{tabular}

(**) Significant for $P>0.01$. 


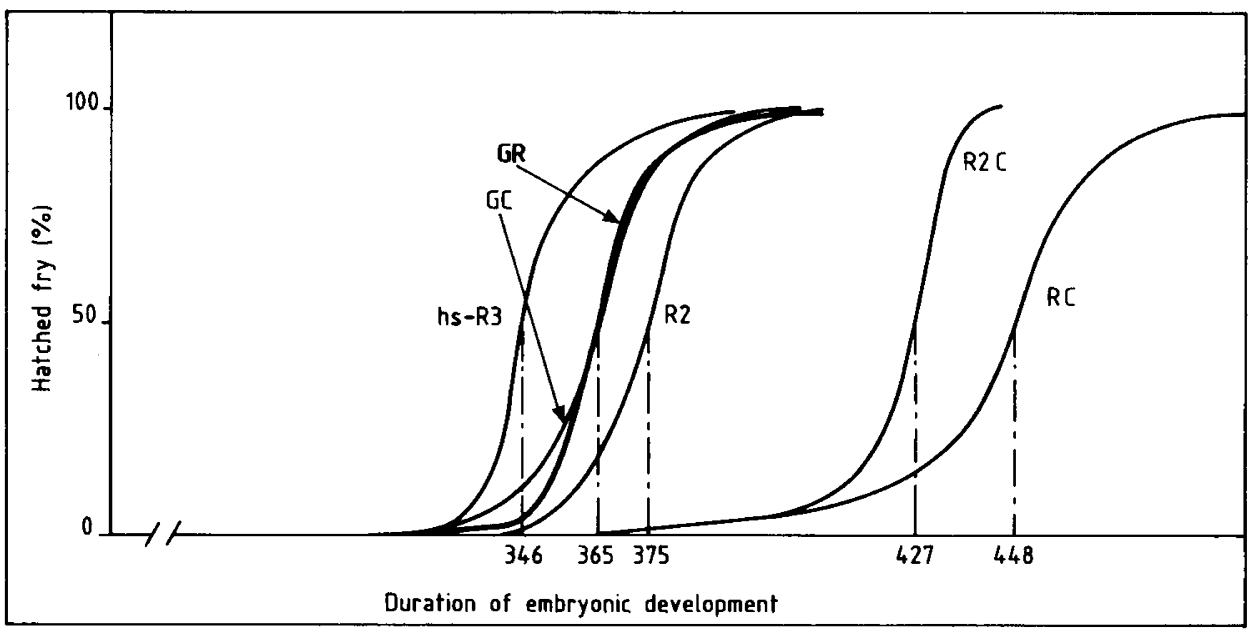

Fig. 1

Hatching curves (experiment I, female 3).

Symbols of the different groups are defined in table 1 ;

duration of embryonic development is expressed in ${ }^{\circ} \mathrm{C} . d$.

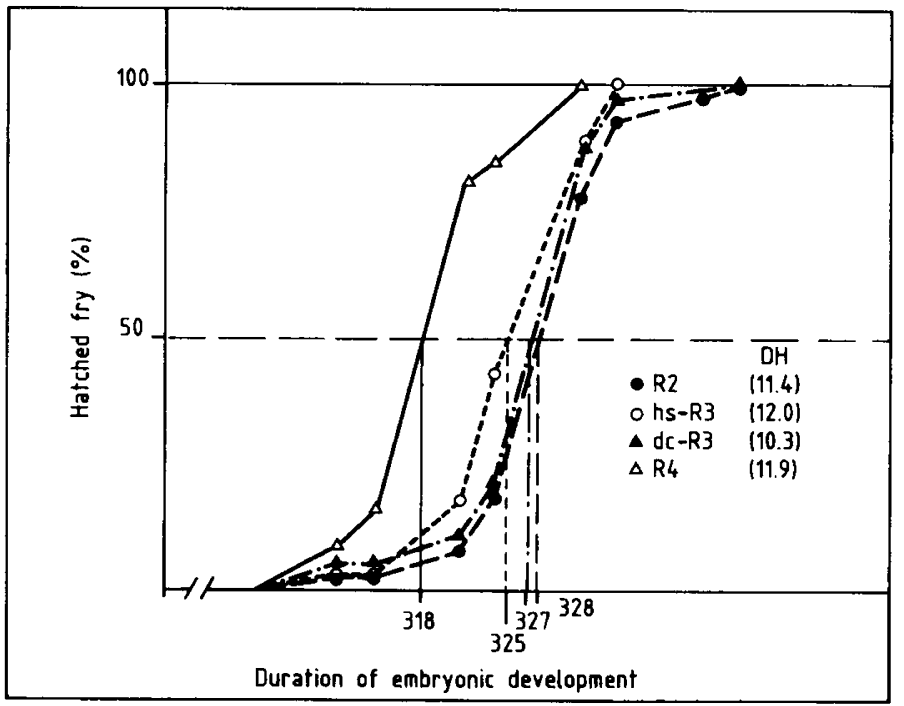

Fig. 2

Hatching curves in experiment 2.

Symbols of the different groups are defined in table 2;

duration of embryonic development and duration of hatching $(D H)$ are expressed in ${ }^{\circ} \mathrm{C} . d$. 


\section{Experiment $n^{o} 2$ (figure 2)}

In agreement with what was observed in experiment 1 , heat-shock triploids hatch before the diploid controls though the absolute reduction of $T H$ appears smaller than in experiment $1\left(2.4^{\circ} \mathrm{C} . \mathrm{d}\right.$, significant for $\left.P<0.01\right)$. Direct-cross triploids also hatch before the diploids but reduction of $T H$ is not as large $\left(1.1^{\circ} \mathrm{C} . \mathrm{d}\right.$, significant for $\left.P<0.05\right)$. However, a paired comparison of the two types of triploids in our experiment shows no significant difference between them. cases).

Tetraploids hatch first ( $T H$ value shorter than for all other groups, $P<0.01$ in all

\section{B. Duration of hatching}

1. Experiment 1 (tables 4 and 5)

- Rainbow trout.

In addition to interactions between female and genetic nature of the progeny, duration of hatching is clearly increased in both triploids and gynogenetics.

- Hybrids.

Both diploid and triploid hybrids have longer $D H$ than the rainbow trout, but conversely to what is observed in pure species, triploid hybrids have a shorter duration of hatching than their diploid hybrid sibs.

\section{Experiment 2}

Mean durations of hatching are extensively shortened when compared to the previous experiment. However, the data confirm that duration of hatching is increased in heat-shock triploids (Student's $t$ test significant for $P<0.01$ ) when compared to the control. A similar increase is observed in tetraploid groups, while direct-cross triploids show a significantly reduced $D H$ (Student's $t$ test significant for $P<0.01$ ).

\section{Discussion}

\section{A. Polyploidy}

Our data show a systematic reduction of the length of embryonic development for all ploidy-type groups. Such a result has already been observed in the case of heatshock triploids by HAPPE et al. (1987).

Several factors may a priori contribute to this observation.

First, polyploidy per se may modify duration of embryonic development : (1) larger cell size (Swarup, 1959) and DNA content of the nucleus can slow down the mitotic rhythm during embryonic development, (2) a lower number of cells per organ (Swarup, 1959) can reduce the number of -mitotic cycles required for embryogenesis, and a nonbalancing of these two opposite phenomena could therefore lead to faster embryonic development in polyploids. 
Anyhow, Oliva-Teles \& Kaushik (1987), who have studied embryonic metabolism in diploid and triploid rainbow trout, could not detect differences between the two groups for energy or nitrogen metabolism.

Secondly, genetic structure of triploids may also modify their developmental pathway. Several authors have detected in diploid populations a positive relationship between heterozygosity and fast developmental rate (DANZMANN et al., 1985, 1986 ; Ferguson et al., 1985 ; KolJonen, 1986). Now, higher heterozygosity in heat shock triploids than in diploids was described in rainbow trout (Allendorf \& LearY, 1984 ; LEARY et al., 1985). Our data are in agreement with these different results, but do not seem consistent with the assumption of LEARY et al. (1985) who suggested from indirect observations (on meristic counts of diploids and triploids) that the two groups should not present large differences in developmental rate.

Finally, thermal shock may also influence kinetics of embryonic development. Several authors have mentionned that heat-shocks applied during early development had a postponing effect on embryonic development (Lindsley \& Poodry, 1977, in Drosophila ; ElsDale \& Davidson, 1987, in frog). Our data would rather suggest an " accelerating " effect of thermal treatment : the fact that direct-cross triploids appear much more similar to the control than heat shock triploids allows this possibility.

Nevertheless, heat shock is not the only feature in which the two types of triploids differ from one another. DiTer et al. (in preparation) have demonstrated that directcross triploids could be more heterozygous than heat shock ones. Earlier hatching of direct-cross triploids should therefore be expected, with regard to the positive relationship between heterozygosity and developmental rate previously described. Their delay in hatching relative to heat shock triploids corroborates the hypothesis of an accelerating effect of heat shock.

\section{B. Gynogenesis}

No significant difference in hatching time between gynogenetic progenies and diploid outbred control can be detected.

Therefore, gynogenesis, and subsequent increase of consanguinity, does not seem to slow down embryonic development, though it strongly affects later growth rate (Chevassus, 1987 ; Quillet et al., unpublished data). Nevertheless, the previously suggested "accelerating effect " of heat shock may interfere with and compensate potential slowing down due to consanguinity, if any. In rainbow trout however, gynogenesis by retention of second polar body results in medium high levels of homozygosity (ThorgaArd et al., 1983 ; Guyomard, 1984 ; Thompson \& ScotT, 1984 ; Allendorf et al., 1986) and study of pure homozygous progenies, i.e. endomitotic gynogenetics (Chourrout, 1984) or androgenetics (Parsons \& ThorgaArd, 1985) should provide complementary data on that purpose.

A larger variability of length of embryonic development is observed in gynogenetic groups. The increase of within group variability in gynogenetic progenies has also been observed for other parameters, like length and weight (Quillet et al., unpublished data) in spite of the theoretically higher genetic similarity between individuals of same maternal origin. However, such a result is frequently observed in inbred populations (LERNER, 1954). 


\section{Hybridization}

We observe for the diploid hybrid between female rainbow trout and male coho salmon a longer incubation period than Chevassus \& Petit (1975) did $\left(450.6^{\circ} \mathrm{C} . \mathrm{d}\right.$ instead of $\left.430^{\circ} \mathrm{C} . \mathrm{d}\right)$ but despite the lack of a coho salmon control in our experiment, we have assumed that the incubation period of the hybrid was near that of the coho salmon as seen by Chevassus \& Petit (1975) and Blanc \& Chevassus (1979).

A noteworthy aspect is that triploidy reduces the incubation period of hybrids. In addition to the hypothesis discussed previously, other factors may be involved in the case of interspecific hybridization, i.e. potential effect of genic balance between the genomes of the different species.

Such phenomena have been described in flatfish by Purdom (1972), who observed that some characteristics such as number of vertebrae or larval pigmentation are inherited additively by diploid hybrids, triploid hybrids and the back-cross between Plaice and Flounder.

Duration of hatching in triploid hybrids is also reduced when compared to the diploids. As in this case triploidy improves survival of hybrids, this reduction may be related to the observation by BLANC \& Chevassus (1979) of a negative correlation between survival rate of an interspecific hybridization and duration of hatching.

It has been observed that in some cases interspecific fertilization could result in very few spontaneous diploid gynogenetics (see Chevassus, 1983, for a review). In the case of simple fertilization, only spontaneously diploid fry (resulting i.e. from nonreduced ova) survive, and are detected, but application of thermal shock may restore viability of haploid gynogenetics, that would normally die, and therefore increase total frequency of gynogenetics in the progeny.

It appears from our data that the large majority of the triploid hybrids hatch after the last rainbow trout larva, but a low frequency of embryos hatch much earlier, and are synchronous with the rainbow trout. These few individuals could therefore be interpreted either as very early hatching hybrids, or as gynogenetic fry. Such fry have not been detected by karyological and biochemical controls of "standard fish " in our study, but long term rearing of the hybrids revealed a low frequency $(3.6 \%$ of the population) of fertile females looking like rainbow trout, that could be gynogenetics (Quillet, 1986). Further study of these early hatched fry should be done in order to determine their status.

Received May 21, 1987.

Accepted September 9, 1987.

\section{References}

Allendorf F.W., Leary R.F, 1984. Heterozygosity in gynogenetic diploids and triploids estimated by gene-centromere recombination rates. Aquaculture, 43, 413-420.

Allendorf F.W., Seeb J.E., Knudsen K.L., Thorgaard G.H., Leary R.F., 1986. Genecentromere mapping of 25 loci in rainbow trout. J. Hered., 77, 307-312.

Benfey J.T., SutTerlin A.M., 1984. Triploidy induced by heat shock and hydrostatic pressure in landlocked Atlantic salmon (Salmo salar L.). Aquaculture, 36, 359-367. 
Billard R., 1977. Utilisation d'un système tris-glycocolle pour tamponner le dilueur d'insémination pour truite. Bull. Fr. Piscic., 264, 102-112.

Blanc J.M., Chevassus B., 1979. Interspecific hybridization of salmonid fish. 1. Hatching and survival up to the $15^{\text {th }}$ day after hatching in $\mathrm{F}_{1}$ generation hybrids. Aquaculture, 18, 21-34.

Chevassus B., 1983. Hybridization in fish. Aquaculture, 33, 245-262.

Chevassus B., 1987. Caractéristiques et performances des lignées uniparentales et des polyplö̈des chez les poissons d'eau froide. In: K. Tiews (ed.), Proc. World Symp. on selection, hybridization and genetic engineering in aquaculture of fish and shellfish for consumption and stocking, Bordeaux, May 27-30, 1986, vol. 2, 145-161, Heenemann Verlagsgesellshaft mb.

Chevassus B., Petrt J., 1975. Hybridation artificielle entre la truite arc-en-ciel (Salmo gairdneri R.) et le saumon coho (Oncorhynchus kisutch W.). Ann Génét. Sél. Anim., 7, 1-11.

Chevassus B., Guyomard R., Chourrout D., Quillet E., 1983. Production of viable hybrids in salmonids by triploidization. Génét. Sél. Evol., 15, 519-532.

Chevassus B., Quillet E., Chourrout D., 1985. La production de truites stériles par voie génétique. Piscic. Fr., 78, 10-19.

Chourrout D., 1980. Thermal induction of diploid gynogenesis and triploidy in the eggs of the rainbow trout, Salmo gairdneri R. Reprod. Nutr. Dév., 20, 727-733.

Chourrout D., 1982. Tetraploidy induced by heat shock $\mathrm{s}$ in the rainbow trout (Salmo gairdneri R.). Reprod. Nutr. Dév., 22, 569-574.

Chourrout D., 1984. Pressure induced retention of second polar body and suppression of first cleavage in rainbow trout eggs : production of all-triploids, all-tetraploids, heterozygous and homozygous diploid gynogenetics. Aquaculture, 36, 111-126.

Chourrout D., Nakayama I., 1987. Chromosome studies of progenies issued from tetraploid females of rainbow trout. Theor. Appl. Genet., 74, 687-692.

Chourrout D., Quillet E., 1982. Induced gynogenesis in the rainbow trout : sex and survival of progenies. Production of all-triploid populations. Theor. Appl. Genet., 63, 201-205.

Chourrout D., Chevassus B., Krieg F., Happe A., Burger G., Renard P., 1986. Production of second generation triploid and tetraploid rainbow trout by mating tetraploid males and diploid females - Potential of tetraploid fish. Theor. Appl. Genet., 72, 193-206.

Danzmann R.G., Ferguson M.M., Allendorf F.W., 1985. Does enzyme heterozygosity influence developmental rate in rainbow trout? Heredity, 56, 417-425.

Danzmann R.G., Ferguson M.M., Allendorf F.W., Knudsen K.L., 1986. Heterozygosity and developmental rate in a strain of rainbow trout (Salmo gairdneri). Evolution, 40, 86-93.

Elsdale T., Davidson D., 1987. Timekeeping by frog embryos, in normal development and after heat shock. Development, 99, 41-49.

Ferguson M.M., Danzmann R.G., Allendorf F.W., 1985. Developmental divergence among hatchery strains of rainbow trout (Salmo gairdneri) 1. Pure strains. Can. J. Genet. Cytol., 27, 289-297.

Finney D.J., 1962. Probit analysis. 318 p., University Press of Cambridge, Cambridge.

Guyomard R., 1984. High level of residual heterozygosity in gynogenetic rainbow trout. Salmo gairdneri Richardson. Theor. Appl. Genet., 67, 307-316.

Happe A., Quillet E., Chevassus B., 1987. Early life history of triploid rainbow trout (Salmo gairdneri R.). Aquaculture (in press).

Johnstone R., 1985. Induction of triploidy in Atlantic salmon by heat shock. Aquaculture, 49, 133-139.

KolJONEN M.L., 1986. The enzyme gene variation of ten finnish rainbow trout strains and the relation between growth rate and mean heterozygosity. Aquaculture, 57, 253-260.

Leary R.F., Allendorf F.W., Knudsen K.L., Thorgaard G.H., 1985. Heterozygosity and developmental stability in gynogenetic diploid and triploid rainbow trout. Heredity, 54, 219225.

LERNER I.M., 1954. Genetic homeostatis. 134 p., Oliver and Boyd, Edinburgh.

Lindsley D.E., Poodry C.A., 1977. A reversible temperature induced developmental arrest in Drosophila. Dev. Biol., 56, 213-218. 
Lou Y.D., Purdom C.E., 1984. Polyploidy induced by hydrostatic pressure in rainbow trout, Salmo gairdneri Richardson. J. Fish. Biol., 25, 345-351.

Luquet P., Durand G., 1970. Evolution de la teneur en acides nucléiques de la musculature épaxiale au cours de la croissance chez la truite arc-en-ciel (Salmo gairdneri). Rôles respectifs de la multiplication et du grandissement cellulaire. Ann. Biol. Anim. Bioch. Biophys., 10, 481-492.

Oliva-Teles A., Kaushik S.J., 1987. Nitrogen and energy metabolism during the early ontogeny of diploid and triploid rainbow trout (Salmo gairdneri R.). Comp. Bioch. Physiol., 87A, 157160.

Onozato H., 1984. Diploidization of gynogenetically activated salmonid eggs using hydrostatic pressure. Aquaculture, 43, 91-98.

Parsons J.E., ThorgaARd G.H., 1985. Production of androgenetic diploid rainbow trout. $J$. Hered., 76, 177-181.

Purdom C.E., 1972. Induced polyploidy in plaice (Pleuronectes platessa) and its hybrid with the flounder (Platichthys flesus). Heredity, 29, 11-24.

Purdom C.E., 1983. Genetic engineering by the manipulation of chromosomes. Aquaculture, 33, 287-300.

Purdom C.E., Thompson D., Lou Y.D., 1985. Genetic engineering in rainbow trout, Salmo gairdneri Richardson, by the suppression of meiotic and mitotic metaphase. J. Fish. Biol., 27, 73-79.

Quillet E., 1986. Contribution à l'étude de la triplö̈die induite chez les salmonidés : conséquences sur les caractéristiques zootechniques. $126 \mathrm{p}$. Thèse de Docteur-Ingénieur, Institut National Agronomique, Paris.

Refstie T., Stoss J., Donaldson E.M., 1982. Production of all-female coho salmon (Oncorhynchus kisutch) by diploid gynogenesis using irradiated sperm and cold shock. Aquaculture, 29, 67-82.

Scheerer P.D., Thorgand G.H., 1983. Increased survival in salmonid hybrids by induced triploidy. Can. J. Fish. Aquat. Sci., 40, 2040-2044.

SNEDECOR G.W., 1956. Statistical methods. 5th ed., 534 p. Iowa state University press, Ames.

SOKAL R.R., RoHLF F.J., 1981. Biometry. The principles and practice of statistics in biological research. 2nd ed., 859 p., Freeman, New York.

Swarup H., 1959. Effect of triploidy on the body size, general organization and cellular structure in Gasterosteus aculeatus (L.). J. Genet., 56, 143-155.

Thомpson D., Scotr A.P., 1984. An analysis of recombination rate in gynogenetic diploid rainbow trout. Heredity, 53, 441-452.

Thorgaard G.H., 1983. Chromosome set manipulation and sex control in fish. In : W.S. Hoar, D.J. Randall, E.M. Donaldson (ed.), Fish physiology, vol. 9, Part B, 405-434, Academic press, New York.

ThorgaArd G.H., 1986. Ploidy manipulation and performance. Aquaculture, 57, 57-64.

Thorgandd G.H., Jazwin M.E., Stier A.R., 1981. Polyploidy induced by heat shock in rainbow trout. Trans. Am. Fish. Soc., 110, 546-550.

ThorgaArd G.H., Allendorf F.W., Knudsen K.L., 1983. Gene centromere mapping in rainbow trout : high interference over long map distances. Genetics, 103, 771-783. 